\section{Toxin genes and cytotoxicity levels detected in Bacillus cereus isolates collected from cooked food products delivered by Swiss Army catering facilities}

\author{
Nicole Heini, Roger Stephan, \\ Sophia Johler
}

Institute for Food Safety and Hygiene, University of Zurich, Switzerland

\begin{abstract}
Heated food is known to be often contaminated with $B$. cereus, leading to cases of diarrhoeal or emetic diseases. Battalion kitchens or army catering facilities present a food safety risk, as temperature abuse and long storage time can result in serious public health problems affecting a high number of served people. In contrast to civil catering facilities, no microbiological monitoring systems are currently implemented in Swiss military kitchens. In this study toxin gene profiles and cytotoxicity levels of 21 isolates of $B$. cereus originating from six different food categories were determined. Nearly all isolates (95\%) harbored the nhe gene, whereas no $h b l$ could be detected. Seven isolates displayed the $c y t K 2$ gene and one cereulide-producer was isolated out of vegetables. While most isolates displayed low cytotoxicity, highly cytotoxic strains were detected, with three isolates even exceeding the cytotoxicity level of the reference strain for high-level toxin production, underpinning that cytotoxicity cannot be deduced only from presence or absence of toxin genes. These findings further underline the importance of rapid cooling of foods or maintenance over $65^{\circ} \mathrm{C}$ before serving. This is especially important in mass catering facilities, such as military kitchens, in which food is often prepared a long time in advance.
\end{abstract}

\section{Introduction}

Bacillus cereus sensu lato (B. cereus s.l.) is a gram-positive bacterium that can be found in different environments and a wide range of foods such as rice, dairy products, spices, and vegetables (Kotiranta et al., 2000; Kramer and Gilbert, 1989). B. cereus $s . l$. is a pathogen that can cause both infec- tion and intoxication. Two different types of $B$. cereus gastrointestinal disease are known, which are caused by different toxins. Cereulide, a heat-stable cyclic peptide, causes foodborne intoxications with the key symptoms of emesis and nausea, whereas the heat-labile enterotoxins - non-hemolytic enterotoxin (Nhe), hemolysin BL ( $\mathrm{Hbl}$ ), and cytotoxin $\mathrm{K}(\mathrm{CytK})$ - produced in the gut of the consumer (foodborne infection) cause diarrhoea (Stenfors Arnesen et al., 2008). While the emetic syndrome is often associated with starchy foods (Stenfors Arnesen et al., 2008), the diarrhoeal form is frequently related to meat, sauces, vegetables and milk products (Kotiranta et al., 2000). Although most cases of illness are self-limiting within a short period of time, severe infections leading to death have been reported (Dierick et al., 2005; Naranjo et al., 2011). Bacterial counts of $10^{5}$ to $10^{8}$ $\mathrm{CFU} / \mathrm{g}$ are considered sufficient to cause harmful effects (Stenfors Arnesen et al., 2008). However, strong strain-specific differences in toxin production have been demonstrated (Guinebretière et al., 2010) and foodborne diseases caused by an infective dose as low as $10^{3}$ to $10^{4}$ bacteria per gram have been reported (Andersson et al., 1995).

The production of highly resistant spores capable of surviving strong environmental stresses represents a main risk factor for the contamination of food products with $B$. cereus. At harvest, spores can be attached to plant materials and can subsequently be transferred to food-processing equipments. Due to their strong adhesive properties and the formation of biofilms, spores are difficult to remove (Andersson et al., 1995). Besides cross-contamination, spores can also survive cooking or pasteurization processes and subsequently germinate and multiply when food is not properly refrigerated (Kramer and Gilbert, 1989). Moreover, the growth possibility of $B$. cereus ranges from thermophilic to psychrotrophic strains, making it difficult to meet food safety regulations (Guinebretière et al., 2008).

Mass catering facilities, such as military kitchens represent a challenge for food safety. Temperature control is crucial, given that often a considerable amount of time passes between cooking and consumption, especially in the case of meals that are served on the field. In particular, heating processes, storage, and recontamination possibilities need to be strictly controlled. Kleer et al. have shown that $B$. cereus is a food safety problem, especially in the catering environment (Kleer et al., 2001). They also showed
Correspondence: Sophia Johler, Institute for Food Safety and Hygiene, Vetsuisse Faculty University of Zurich, Winterthurerstr. 272, CH-8057 Zurich, Switzerland.

Tel.: +41.446358680 - Fax: +41.446358908 .

E-mail: sophia.johler@uzh.ch

Key words: Bacillus cereus group, Cooked food, Toxin gene profiles, Cytotoxicity, Army catering facility.

Acknowledgments: this work was supported by a grant from the Swiss National Science Foundation (IZK0Z3 168981/1). The funding source was not involved in the study design, data collection, or analysis.

Contributions: the authors contributed equally.

Conflict of interest: the authors declare no potential conflict of interest.

Funding: none.

Received for publication: 1 February 2018.

Revision received: 5 April 2018.

Accepted for publication: 10 April 2018.

This work is licensed under a Creative Commons Attribution-NonCommercial 4.0 International License (CC BY-NC 4.0).

(C) Copyright N. Heini et al., 2018

Licensee PAGEPress, Italy

Italian Journal of Food Safety 2018; 7:7323 doi:10.4081/ijfs.2018.7323

that $B$. cereus was responsible for $52 \%$ of diarrhoea outbreaks from 1994-1997 in the German Armed Forces. Furthermore, Ernst et al. reported a prevalence of $14 \%$ for $B$. cereus on surfaces in catering facilities in the German Army, pointing out that crosscontamination is a real problem during food preparation (Ernst et al., 2001). In case of the Swiss Army, the food safety concept is based on the food law and comprises three key factors: education, good hygiene practices and self-control. Recently, two studies were performed providing first baseline data about the microbiological quality of cooked foods from battalions' kitchens and Swiss Army catering facilities (Hunziker, 2016; Ruf and Stephan, 2017). The aim of the present study was to further characterize 21 isolates of $B$. cereus originating from cooked food collected from these army kitchens. Molecular characterization was based on toxin gene profiling. Moreover, as the occurrence of enterotoxin genes does not allow for conclusions regarding toxin levels produced, the cytotoxic potential of all isolates was determined. 
modifications. The GoTaq PCR system was used at the following cycling conditions: i) 2 min at $95^{\circ} \mathrm{C}$, ii) $30 \times\left[45 \mathrm{~s}\right.$ at $95^{\circ} \mathrm{C}, 45 \mathrm{~s}$ at $51^{\circ} \mathrm{C}, 2 \mathrm{~min}$ at $72^{\circ} \mathrm{C}$; iii) $5 \mathrm{~min}$ at $72^{\circ} \mathrm{C}$. In order to distinguish between cytK1 and cytK2, a duplex PCR was performed (Guinebretière et al., 2006). The following strains were used as positive controls for the different toxin gene PCRs: WSBC10028 (nhe, cytK, ces), CH-35 (nhe, hbl, cytK), NVH0391/98 (cytK1), NVH0674/98 (cytK2).

\section{Cytotoxicity assay}

Cytotoxicity of all isolates was determined in a Vero cell assay using WST-1 (Sigma-Aldrich, St. Louis, MO) as described elsewhere (Moravek et al., 2006). Cell-free culture supernatants were produced by growing the strains in $30 \mathrm{ml} \mathrm{CGY}$ broth in an Erlenmeyer flask. The cultures were adjusted to an $\mathrm{OD}_{600}$ of 0.05 using an overnight culture of the isolate. The day al. (Ehling-Schulz et al., 2006) with minor cultures were grown to an OD of 7 at $30^{\circ} \mathrm{C}$ (120 rpm shaking) and were subsequently centrifugated at $11000 \mathrm{rpm}$ for $10 \mathrm{~min}$ and filtrated through $0.2 \mu \mathrm{m}$ sterile filtres. Aliquots of $1 \mathrm{~mL}$ supernatants were supplemented with $10 \mathrm{uL} 0.1 \mathrm{M} \mathrm{Na} 2$ EDTA and stored at $-80^{\circ} \mathrm{C}$. Reference strains for low (RIVM Bc90) and high-level of toxin production (NVH 0075-95) were included in every run.

\section{Results}

Nearly all strains (95\%) harbored the nhe gene, whereas no $h b l$ gene could be detected. Seven strains displayed the $c y t K 2$ gene which originated from different food categories. Moreover, one cereulide-producing strain was isolated out of vegetables. Tables 1 and 2 give an overview of the results of PCR-based screening for toxin genes carried by the isolates.

While all isolates were cytotoxic, a wide range of cytotoxicity levels could be detected (Figure 1). There was no correlation between food product and cytotoxic potential of the isolate. Three strains exceeded the cytotoxic level of the reference strain for high-level toxin production. They originated from pork sausage, tomato sauce, and French browned potatoes (Pommes Risolées). The product showing the highest $B$. cereus counts was tomato sauce.

\section{Discussion}

EFSA stated that foodborne illness caused by $B$. cereus has been associated with almost all categories of food products (European Food Safety Authority, 2005). In the present study, B. cereus was detected in a wide range of different foods, which is consistent with its ubiquitous presence.

The finding that nearly all isolates in this study harbored the nhe gene is in accordance with other studies (Guinebretière et al., 2010; Moravek et al., 2006). However, it is uncommon that no $h b l$ gene could be detected, given that this gene is normally

Table 2. Distribution of toxin genes found in the B. cereus isolates based on their food origin.

\begin{tabular}{lcccccc} 
Toxin genes & $\begin{array}{c}\text { Meat dishes, } \\
\mathrm{n}=3(\%)\end{array}$ & $\begin{array}{c}\text { Starchy side dishes or pasta, } \\
n=6(\%)\end{array}$ & $\begin{array}{c}\text { Vegetables, } \\
n=5(\%)\end{array}$ & $\begin{array}{c}\text { Sauces, } \\
n=2(\%)\end{array}$ & $\begin{array}{c}\text { Soup, } \\
n=1(\%)\end{array}$ & $\begin{array}{c}\text { Teas, } \\
n=4(\%)\end{array}$ \\
nhe & $3(100)$ & $6(100)$ & $4(80)$ & $2(100)$ & $1(100)$ & $4(100)$ \\
$h b l$ & $0(0)$ & $0(0)$ & $0(0)$ & $0(0)$ & $0(0)$ & $0(0)$ \\
\hline cytK2 & $3(100)$ & $1(17)$ & $2(40)$ & $0(0)$ & $1(100)$ & $1(25)$ \\
ces & $0(0)$ & $0(0)$ & $1(20)$ & $0(0)$ & $0(0)$ & $0(0)$ \\
\hline
\end{tabular}


Normalized reciprocal titre

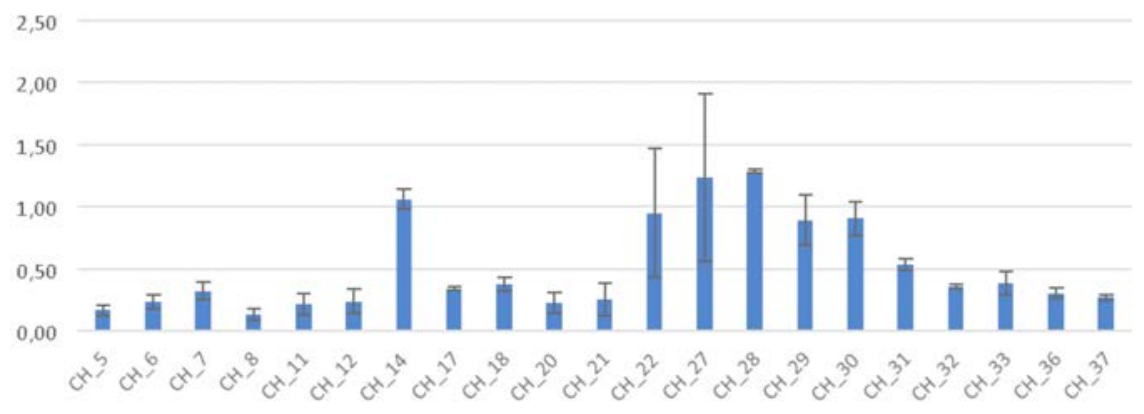

Figure 1. Reciprocal titres displayed by the $21 \mathrm{~B}$. cereus isolates. A reciprocal titre of 1.00 equals a cytotoxicity level identical to the cytotoxicity of the highly toxic reference strain.

present with a frequency of $40 \%$ to $97 \%$ (Guinebretière et al., 2010).

Several studies have stated that cereulide-producing strains are often associated with rice and pasta (Dierick et al., 2005; Naranjo et al., 2011). Although starch-degrading properties are linked to the production of cereulide (Choma et al., 2000), the cereulide-producing strain detected in this study was isolated out of vegetables. Such findings have also been made by Messelhäusser et al. isolating emetic strains out of a wide variety of food products (Messelhäusser et al., 2014). Cereulide is a heat- and acid-stable toxin able to survive cooking processes. The potential for cereulide formation cannot be solely predicted from the presence of the ces-gene, but also depends on external parameters such as the food matrix (Rajkovic et al., 2006). Kreuzberger has shown that $50 \%$ of all detected cereulideproducing strains in catering facilities of the German army were isolated from the staff's hands (Kreuzberger, 2007). Interestingly, these isolates were associated with higher Nhe toxin titres compared to isolates collected from equipment surfaces. This finding underlines the importance of personal hygiene and shows the potential risk of cross-contamination with cereulide-positive strains, which are in general rarely isolated from the environment (Messelhäusser et al., 2014).

nhe is implicated as the most dominant diarrhoeal toxin, and correlation of cytotoxicity with Nhe concentration in supernatants has been described (Moravek et al., 2006). However, the cytotoxic potential of the strain lacking the nhe gene $\left(\mathrm{CH} \_33\right)$ in our study did not differ from the other isolates. Most isolates displayed middle or low cytotoxicity, which is consistent with the study from Kreuzberger (Kreuzberger, 2007). There, $16 \%$ of all strains were classified as high-level toxin-producers, which is in accordance with the present study showing that $14 \%$ of all isolates were more toxic than the reference strain. The isolate present with the highest bacterial counts also exhibited high level cytotoxicity (strain $\mathrm{CH}_{-}$27).

\section{Conclusions}

As shown in this study, the level of cytotoxicity is highly variable between isolates, ranging from barely toxic to highly toxic. Besides temperature control of heated foods, it is important to avoid contamination of kitchen surfaces with soil and dust to reduce the risk of foodborne illness caused by $B$. cereus. Meticulous hygienic procedures are essential to reduce cross-contamination. Therefore, cleaning and disinfection of equipments with agents exhibiting sporicidal activity is of highly importance (Ernst et al., 2006).

\section{References}

Andersson A, Ronner U, Granum P, 1995. What problems does the food industry have with the spore-forming pathogens Bacillus cereus and Clostridium perfringens? Int J Food Microbiol 28:145-55.

Choma C, Guinebretière MH, Carlin F, Schmitt P, Velge P, Granum P, NguyenThe C, 2000. Prevalence, characterization and growth of Bacillus cereus in commercial cooked chilled foods containing vegetables. J Appl Microbiol 88: 617-25.

Dierick K, Van Coillie E, Swiecicka I, Meyfroidt G, Devlieger H, 2005. Fatal family outbreak of Bacillus cereusassociated food poisoning. J Clin Microbiol 43:4277-9.
Ehling-Schulz M, Guinebretière $\mathrm{MH}$, Monthan A, Berge O, Fricker M, Svensson B, 2006. Toxin gene profiling of enterotoxic and emetic Bacillus cereus. FEMS Microbiol Lett 260:23240.

Ernst C, Schulenburg J, Klein G, 2001. Bacillus cereus in Verpflegungseinrichtungen der Bundeswehr-Vorkommen und Bedeutung im Zusammenhang mit 1 e b e n s m i t e 1 b e d i n g t e n Gruppenerkrankungen sowie Ursachen und mögliche Vorsorgemassnahmen. Arch Lebensm Hyg 52:80-3.

Ernst C, Schulenburg J, Jakob P, Dahms S, Lopez A, Nychas G, Klein G, 2006. Efficacy of amphoteric surfactant- and peracetic acid-based disinfectants on spores of Bacillus cereus in vitro and on food premises of the German armed forces. J Food Prot 69:1605-10.

European Food Safety Authority. 2005. Bacillus cereus and other Bacillus spp. in foodstuffs. EFSA J 175:1-48.

Guinebretière MH, Fagerlund A, Granum P, Nguyen-The C, 2006. Rapid discrimination of cytK-1 and cytK-2 genes in Bacillus cereus strains by a novel duplex PCR system. FEMS Microbiol Lett 259:74-80.

Guinebretière MH, Thompson F, Sorokin A, Normand P, Dawyndt P, Ehling-Schulz M, De Vos P, 2008. Ecological diversification in the Bacillus cereus group. Environ Microbiol 10:851-65.

Guinebretière $\mathrm{MH}$, Velge $\mathrm{P}$, Couvert $\mathrm{O}$, Carlin F, Debuyser ML, Nguyen-The C, 2010. Ability of Bacillus cereus group strains to cause food poisoning varies according to phylogenetic affiliation (groups I to VII) rather than species affiliation. J Clin Microbiol 48:338891.

Hunziker S, 2016. Untersuchungen zur mikrobiologischen Qualität von erhitzten Lebensmitteln aus Bataillonsküchen der Schweizer Armee. Zürich: University of Zurich, VetsuisseFakultät.

Kleer J, Bartholomä A, Levetzow R, Reiche T, Sinell H, Teufel P, 2001. Bakterielle Lebensmittel-Infektionen und Intoxikationen in Einrichtungen zur Gemeinschaftsverpflegung 1985-2000. Arch Lebensm Hyg 52:76-9.

Kotiranta A, Lounatmaa K, Haapasalo M, 2000. Epidemiology and pathogenesis of Bacillus cereus infections. Microbes Infect 2:189-98.

Kramer J, Gilbert R, 1989. Bacillus cereus and other Bacillus species. Food borne bacterial pathogens, 21-77. New York: Doyle MP. 
Kreuzberger C, 2007. Charakterisierung der Toxizität von Bacillus cereus Isolaten aus Verpflegungseinrichtungen der Bundeswehr. München: Institut für Hygiene und Technologie der Lebensmittel tierischen Ursprungs der Tierärztlichen Fakultät der Universität München.

Messelhäusser U, Frenzel E, Blöchinger C, Zucker R, Kämpf P, Ehling-Schulz M, 2014. Emetic Bacillus cereus are more volatile than thought: recent foodborne outbreaks and prevalence studies in Bavaria (2007-2013). Biomed Res Int 2014:465603.
Moravek M, Dietrich R, Buerk C, Broussolle V, Guinebretière $\mathrm{MH}$, Granum P, Märtlbauer E, 2006. Determination of the toxic potential of Bacillus cereus isolates by quantitative enterotoxin analyses. FEMS Microbiol Lett 257:293-8.

Naranjo M, Denayer S, Botteldoorn N, Delbrassinne L, Veys J, Waegenaere J, Dierick K, 2011. Sudden death of a young adult associated with Bacillus cereus food poisoning. J Clin Microbiol 49:4379-81.

Rajkovic A, Uyttendaele M, Ombregt S, Jaaskelainen E, Salkinoja-Salonen M,
Debevere J, 2006. Influence of type of food on the kinetics and overall production of Bacillus cereus emetic toxin. J Food Prot 69:847-52.

Ruf R, Stephan R, 2017. Mikrobiologische Qualität von erhitzten Lebensmitteln aus Verpflegungszentren der Schweizer Armee. Rundschau für Fleischhygiene und Lebensmittelüberwachung.

Stenfors Arnesen L, Fagerlund A, Granum P, 2008. From soil to gut: Bacillus cereus and its food poisoning toxins. FEMS Microbiol Rev 32:579-606. 